\title{
Karakteristik Sosial Ekonomi Petani Pembudidaya Ikan Air Tawar Di Sleman Yogyakarta
}

\section{Socioeconomic Characteristics of Freshwater Fish Farmers In Sleman District, Yogyakarta}

\author{
Edy Suwasono $^{1^{*}}$, Ratna Dewi Mulyaningtiyas ${ }^{2}$ \\ ${ }^{1 *}$ Program Studi Manajemen, Pascasarjana, Universitas Islam Kadiri, J1.Sersan Suharmaji No.38, \\ Manisrenggo Kec.Kota, Kediri, Indonesia \\ ${ }^{2}$ Program Studi Agribisnis, Pascasarjana, Universitas Islam Kadiri, Jl.Sersan Suharmaji No.38, \\ Manisrenggo Kec.Kota, Kediri, Indonesia
}

Diterima: 29 Agustus 2019; Direvisi: 27 November 2019; Disetujui: 1 Desember 2019

\begin{abstract}
ABSTRAK
Sektor perikanan terutama perikanan air tawar di Daerah Istimewa Yogyakarta cenderung terus meningkat, dan bahkan mampu menyumbang $96 \%$ dari total produksi perikanan. Karakteristik sosial ekonomi petani dan peran kelembagaan merupakan indikator-indikator penting untuk mengetahui kinerja usahatani tambak ikan air tawar. Tujuan penelitian untuk mendiskripsikan karakteristik sosial ekonomi petani budidaya air tawar. Penentuan lokasi dan sampel dilakukan secara purposive di Desa Sidomoyo, Kecamatan Godean, Kabupaten Sleman (DIY). Jumlah sampel adalah sebanyak 30 orang. Metode penelitian adalah survei Hasil penelitian menunjukkan, 83,33\% petani berada pada usia produktif dari jumlah 30 orang; $80 \%$ pendidikan formal petani hanya mencapai SD-SLTP; 86,67\% rata-rata jumlah tanggungan yaitu 3 orang/keluarga; $90 \%$ petani rata-rata berpengalaman 5 tahun - 10 tahun; rata-rata produksi ikan mencapai $2.600 \mathrm{~kg}$ per periode usaha; sistem penjualan dengan cara berlangganan, dengan harga jual rata-rata Rp 17.000/kg dan merupakan harga yang berlaku di pasar. Karakteristik sosial ekonomi petani sangat berpengaruh terhadap kinerja usahatani pembudidaya ikan air tawar.
\end{abstract}

Kata kunci: budidaya ikan; pembudidaya; karakteristik petani; sosial ekonomi; kinerja usahatani

\section{ABSTRACT}

The fisheries sector, especially freshwater fisheries in the Special Region of Yogyakarta tends to continue to increase, and even able to contribute $96 \%$ of total fisheries production. Socio-economic characteristics of farmers and the role of institutions are important indicators to determine the performance of freshwater fish pond farming. The purpose of the study was to describe the socioeconomic characteristics of freshwater aquaculture farmers. Determination of location and sample is done purposively in Sidomoyo Village, Godean District, Sleman Regency (DIY). The number of samples are 30 peoples and the method was a survey. The results showed that $83.33 \%$ of farmers were of productive age; $80 \%$ of farmers' formal education only reaches SD-SLTP; $86.67 \%$ the average number of dependents is 3 people / family; $90 \%$ of farmers have an averages of 5 years - 10 years experience; average fish production reaches 2,600 kg per business period; sales system by way of a subscription, with an average selling price of Rp. 17,000 / kg. The socio-economic characteristics of farmers greatly affect the performance of freshwater fish farming.

Keywords: fish farming; farming; farmer's characteristics; socio-economic; farming performance

\section{How to Cite:}

Suwasono, E., \& Mulyaningtiyas, R. D. (2019). Karakteristik Sosial Ekonomi Petani Pembudidaya Ikan Air Tawar Di Sleman Yogyakarta. HABITAT, 30(3), 105-110. https://doi.org/10.21776/ub.habitat.2019.030.3.13 


\section{Pendahuluan}

Pengembangan usaha budidaya perikanan diperlukan suatu kelembagaan yang mampu mengelola Sumber Daya Manusia dan Sumber Daya Alam, sehingga tujuan yang telah ditentukan dapat tercapai. Kelembagaan adalah aturan perilaku yang mengatur pola tindakan dan hubungan. Kelembagaan dapat menggambarkan pola perilaku dan hubungan suatu organisasi tertentu dalam hubungannya dengan lingkungan atau sumberdaya (Ruttan dalam Widodo,et.al.2015). Kelembagaan adalah kelompok-kelompok sosial yang menjalankan masyarakat., kelembagaan memiliki tujuan tertentu, dan orang-orang yang terlibat di dalamnya memiliki pola perilaku tertentu serta nilai-nilai dan norma yang sudah disepakati yang sifatnya khas. Dari sudut pandang psikologis, kelompok sebagai suatu gerakan faktor psikis sebagai sesuatu yang determinan dengan karakteristik sebagai berikut : persepsi dan kognisi kelompok, motivasi dan pemuasan kebutuhan, group goals (tujuan kelompok), organisasi kelompok, saling ketergantungan masing-masing anggota kelompok, serta interaksi (Shaw,1979).

Peran serta kelembagaan usaha pertanian diperlukan agar diperoleh hasil ekonomis yang lebih optimal sehingga dapat meningkatkan kinerja usahatani yang dilandasi dengan jiwa kewirausahaan. Provinsi Daerah Istimewa Yogyakarta mempunyai lima kabupaten dan satu kota, Data perikanan tahun 2014 mencatat bahwa produksi perikanan mencapai $67.687,5$ ton atau naik sebesar 12,39 persen dibandingkan dengan tahun 2013 tercatat sebesar 60.226,6 ton. Sekitar 95,98 persen dari total produksi perikanan merupakan hasil budidaya perikanan darat dan selebihnya 4,02 persen adalah hasil perikanan laut (BPS, 2014). Produksi terbesar perikanan darat berasal dari budidaya di kolam yang mencapai $62.238,32$ ton $(95,80$ persen). Nilai produksi perikanan sebesar Rp.1.238,91 milyar, atau naik sebesar 53,58 persen dibanding tahun sebelumnya yang sebesar Rp. 806,7 milyar (BPS, 2014).

Faktor sosial ekonomi merupakan suatu kondisi/keadaan petani mengenai keadaan sosial yang dapat mendukung kegiatan usahatani yag berasal dari lingkungan mereka sendiri dan

*Penulis Korespondensi

E-mail: Suwasono_edy@yahoo.co.id tumbuh dari kesadaran mereka sendiri. Kondisi faktor sosial ekonomi petani akan mempengaruhi peranan petani anggota kelompok tani terhadap pengembangan kelembagaannya. Penggunaan lahan Desa Sidomoyo sebagian besar berasal dari lahan sawah yang sudah tidak produktif lagi untuk ditanami padi. Kondisi demikian menyebabkan lahan persawahan tidak dapat ditanami sebagaimana mestinya sehingga mendorong masyarakat setempat untuk memanfaatkan lahan tersebut menjadi area pembudidaya ikan tawar (nila). Penelitian ini bertujuan untuk mendiskripsikan karakteristik sosial ekonomi petani pembudidaya ikan air tawar Di Sleman Yogyakarta.

\section{Metodelogi Penelitian}

Metode dasar yang digunakan dalam penelitian adalah metode penelitian deskriptif. Koentjaraningrat (1997) menyatakan penelitian deskriptif (descriptive research) bertujuan untuk menggambarkan secara tepat sifat-sifat suatu individu, keadaan gejala atau kelompok tertentu, atau untuk menentukan frekuensi atau penyebaran suatu gejala atau frekuensi adanya hubungan tertentu antara suatu gejala dan gejala lain dalam masyarakat. Secara lebih lanjut penggunan metode yang bersifat deskriptif dapat memberikan gambaran yang jelas mengenai suatu individu, keadaan gejala atau kelompok tertentu. Penelitian kualitatif digunakan untuk menggambarkan karakteristik sosial ekonomi pembudidaya ikan di Desa Sidomoyo. Penelitian ini menggunakan penelitian survei suatu teknik pengumpulan informasi yang dilakukan dengan cara menyusun pertanyaan dalam bentuk kuisioner yang diajukan kepada responden dalam bentuk sampel dari sebuah populasi sebagai alat pengumpul data, data dikumpulkan dari sampel yang dapat mewakili seluruh populasi yang ada di lokasi penelitian.

Lokasi penelitian ditentukan dengan metode purposive yaitu dengan memilih lokasi penelitian di Daerah Istimewa Yogyakarta (DIY) pada Kabupaten Sleman di Desa Sidomoyo dengan pertimbangan Sleman merupakan penghasil ikan tertinggi di D.I.Yogyakarta. Metode pengambilan responden ditentukan dengan metode purposive yaitu menentukan responden sesuai dengan tujuan penelitian, menentukan responden dengan pertimbangan tertentu (Sugiyono, 2012) yaitu kelompok tani pembudidaya ikan berdasarkan klasifikasi kelas pemula yaitu sebanyak 30 responden. Metode 
pengumpulan data yang dilakukan dalam penelitian ini menggunakan cara dokumentasi, wawancara, observasi. Data yang terkumpul dianalisis secara diskriptif yaitu mendiskripsikan status sekelompok manusia, suatu obyek, suatu set kondisi, suatu sistem pemikiran ataupun suatu kelas peristiwa pada masa sekarang (Nasir, 2003 : 77). Deskriptif kualitatif menggunakan bantuan alat kuantitatif melalui skor. Pemberian skor dengan menggunakan Skala Likert. Skala likert digunakan untuk mengukur sikap, pendapat dan persepsi seseorang atau sekelompok tentang kejadian atau gejala sosial (Riduwan, 2002).

\section{Hasil dan Pembahasan}

Keadaan sosial ekonomi ini berasal dari kesadaran dan kemampuan petani, sehingga keadaan sosial masing-masing petani sangat beragam. Kondisi faktor sosial ekonomi petani akan mempengaruhi peranan petani anggota kelompok tani pembudidaya ikan. Dengan adanya kelompok tani ini mereka bisa mengembangkan kemampuan yang ada pada dirinya untuk menciptakan ide-ide kreatif demi kemajuan kelompok dan meningkatkan pendapatan/perekonomian rumah tangga petani.

Pembangunan ekonomi pada umumnya dan ekonom pertanian khususnya memiliki telah lama berfokus pada bagaimana pertanian dapat berkontribusi terbaik untuk pertumbuhan ekonomi secara keseluruhan dan modernisasi (Pingali, 2006). Hasil penelitian ini sesuai dengan pendapat Mardikanto 1995, bahwa petani yang memiliki tingkat pendapatan yang lebih tinggi biasanya akan lebih progresif dalam mengadopsi atau menerapkan cara baru akan menyisihkan sebagian keuntungan untuk investasi usahatani atau tambahan modal usahatani.

Keadaan sosial yaitu a) umur mempengaruhi anggota kelompok dalam meningkatkan kinerja dan menciptakan iklim organisasi yang kondusif. Semakin bertambahnya umur seseorang maka akan meningkatkan kemampuan berfikir dan bertindak seseorang tersebut. Tetapi pada batas usia tertentu maka kemampuan tersebut akan menurun. Sedangkan dalam hal pengalaman semakin bertambah usia petani semakin menjadi lebih matang dalam pengalamannya (Soekartawi, 1988). Data mengenai karakteristik umur anggota kelompok tani pembudidaya ikan di Desa Sidomoyo, Kabupaten Sleman dapat dilihat pada tabel berikut ini;
Tabel 1. Pengelompokan pembudidaya berdasarkan umur.

\begin{tabular}{lrr}
\hline Umur (tahun) & Jumlah (orang) & (\%) \\
\hline $20-30$ & 2 & 6,67 \\
$31-40$ & 12 & 40,00 \\
$41-50$ & 13 & 43,33 \\
$\geq 51$ & 3 & 10,00 \\
\hline Jumlah & 30 & 100,00 \\
\hline
\end{tabular}

Berdasarkan tabel 1, terlihat bahwa jumlah penduduk berdasarkan umur adalah berada pada usia produktif/usia kerja $31-50$ tahun yaitu sejumlah 25 orang atau $80,33 \%$ dari total responden. Hal ini menunjukkan bahwa Desa Sidomoyo merupakan desa yang sedang berkembang dan memiliki potensi tenaga kerja yang sangat besar. Selain itu hal tersebut menunjukkan bahwa penduduk di Desa Sidomoyo mempunyai kualitas yang baik sehingga akan lebih mudah dalam menerima suatu inovasi teknologi.

Petani dengan kisaran umur lebih dari 51 tahun yang termasuk dalam kategori tidak produktif. Petani umur 31-50 tahun memiliki fisik yang potensial untuk mendukung kegiatan usahatani, dinamis, kreatif, dan cepat dalam menerima inovasi teknologi baru. Petani berumur lebih dari 59 tahun memiliki kelebihan dalam hal pengalaman, pertimbangan, etika kerja dan komitmen terhadap mutu. Kekurangan dari petani dengan umur lebih dari 51 tahun adalah sering dianggap kurang luwes dan menolak teknologi baru (Sunar, 2012)

b) Pendidikan dinilai sebagai sarana meningkatkan pengetahuan tentang teknologi pertanian baru (Soekartawi, 1988). Menurut Denta (2008) pendidikan merupakan sarana belajar, dimana selanjutnya diperkirakan akan menanamkan pengertian sikap yang lebih menguntungkan menuju penggunaan praktek pertanian yang lebih menguntungkan dan modern. Dengan tingkat pendidikan yang lebih tinggi maka pengetahuan akan lebih banyak sehingga mudah menciptakan partisipasi dari seseorang. Pendidikan adalah salah satu faktor penting dalam peningkatan kualitas sumberdaya manusia, baik secara formal maupun informal. Tingkat pendidikan ini meliputi jenjang pendidikan mulai dari SD, SLTP, SLTA dan perguruan tinggi. Keadaan penduduk di Desa Sidomoyo berdasarkan tingkat pendidikan dapat digolongkan dalam beberapa tingkatan, yaitu (1) Tidak sekolah; (2) Tamat SD/sederajat (3) Tamat SLTP/sederajat; (4) Tamat SLTA/sederajat. 
Berdasarkan tingkat pendidikan, pada tabel berikut ini dijelaskan distribusi penduduk.

Tabel 2. Pengelompokkan petani berdasarkan tingkat pendidikan

\begin{tabular}{lrr}
\hline Tingkat pendidikan & Jumlah (orang) & $(\%)$ \\
\hline Tidak sekolah & 2 & 6,67 \\
SD & 13 & 43,33 \\
SLTP & 11 & 36,67 \\
SLTA & 4 & 13,33 \\
\hline Jumlah & 30 & 100,00 \\
\hline
\end{tabular}

Pada tabel 2 dapat diketahui bahwa komposisi penduduk menurut tingkat pendidikan di Desa Sidomoyo adalah dari SD - SLTP sebesar $80,00 \%$. Hal ini dapat disimpulkan secara keseluruhan penduduk di Desa Sidomoyo pernah mengenyam bangku sekolah. Oleh karena itu, penyampaian informasi lebih cepat diterima dan diterapkan oleh penduduk baik informasi yang diberikan oleh PPL ataupun pihak lain dapat langsung diterima tanpa adanya pengulangan informasi. Selain itu, penduduk juga dapat mencari informasi sendiri yang sesuaui dengan kebutuhannya. Semakin tinggi tingkat pendidikan, semakin besar probabilitas perempuan yang bekerja.

Payaman (1985) menjelaskan semakin tinggi pendidikan, akan menjadikan waktu yang dimiliki menjadi mahal, dan keinginan untuk bekerja semakin tinggi. Sebaliknya, semakin rendah tingkat pendidikan, akses pekerjaan pun sangat terbatas. Terbatasnya akses pendidikan ini menyebabkan perempuan bekerja pada kegiatan pertanian.

c) Tanggungan keluarga merupakan anggota keluarga yang belum dapat menghasilkan pendapatan sendiri bagi dirinya, dan menjadi tanggung jawab kepala keluarga yang dalam hal ini adalah petani sampel.

Tabel 3. Pengelompokan Petani Ikan Berdasarkan Jumllah Tanggungan Anggota Keluarga

\begin{tabular}{lrc}
\hline $\begin{array}{l}\text { Jumlah anggota keluarga } \\
\text { petani ikan (orang) }\end{array}$ & $\begin{array}{c}\text { Jumlah } \\
\text { (orang) }\end{array}$ & \multicolumn{1}{c}{ (\%) } \\
\hline Tidak Memiliki & 3 & 10,00 \\
$1-2$ & 21 & 70,00 \\
$3-5$ & 5 & 16,67 \\
$\geq 6$ & 1 & 3,33 \\
\hline Jumlah & 30 & 100,00 \\
\hline
\end{tabular}

Berdasarkan Tabel 3 menunjukkan bahwa $86,67 \%$ anggota memiliki tanggungan keluarga 1-5. Menurut Soekartawi (1988), menyatakan bahwa anggota keluarga sering dijadikan bahan pertimbangan dalam pengambilan keputusan untuk menerima inovasi. Sedangkan menurut pendapat Mosher (1987) yang cenderung menyebutkan pentingnya peranan masing-masing anggota keluarga yang telah dewasa dalam mempengaruhi keputusan yang diambil oleh kepala keluarga. Tanggungan keluarga merupakan salah satu alasan utama bagi para wanita rumah tangga turut serta dalam membantu suami untuk memutuskan diri untuk bekerja memperoleh penghasilan.

Semakin banyak responden mempunyai anak dan tanggungan, maka waktu yang disediakan responden untuk bekerja semakin efektif (Sihol Situngkir, 2007). Namun kenyataan di lapang besarnya jumlah anggota keluarga tidak mempengaruhi petani dalam mengikuti berusahatani ikan. Karena bagi petani yang memiliki jumlah anggota keluarga yang besar akan mempunyai motivasi yang tinggi untuk memenuhi kebutuhannya, sehingga mereka harus berusaha keras untuk memenuhinya tanpa meminta pertimbangan dari keluarga. Sedangkan untuk anggota kelompok yang mempunyai jumlah tanggungan keluarga lebih sedikit memiliki kemampuan lebih cepat dalam mengadopsi suatu inovasi dibandingkan dengan petani yang jumlah anggotanya banyak, karena mereka masih memerlukan pendapat dan pertimbangan yang harus dipikirkan bersama demi memenuhi kebutuhan anggota keluarganya tersebut.

d) Lama berusahatani adalah berapa lama petani telah bekerja sebagai pembudidaya ikan

Tabel 4. Lama berusahatani ikan

\begin{tabular}{lrr}
\hline $\begin{array}{c}\text { Lama Menggeluti } \\
\text { Usahatani Ikan } \\
\text { (Tahun) }\end{array}$ & $\begin{array}{c}\text { Jumlah } \\
\text { (Orang) }\end{array}$ & $\begin{array}{c}\text { Persentase } \\
(\%)\end{array}$ \\
\hline$<1$ & 1 & 3,33 \\
$1-5$ & 10 & 33,33 \\
$6-10$ & 17 & 56,67 \\
$>10$ & 2 & 6,67 \\
\hline Jumlah & 30 & 100,00 \\
\hline
\end{tabular}

Berdasarkan tabel di 4 90\% petani ratarata berpengalaman 5 tahun - 10 tahun, semakin lama seseorang menggeluti usahatani maka petani akan mempunyai banyak pengalaman dan mampu mengembangkan usahanya.

Penetapan harga jual adalah proses penentuan apa yang akan diterima suatu perusahaan dalam penjualan produknya. Berdasarkan pengelompokkan petani menurut 
penentuan harga jual sebanyak $80 \%$ ditentukan dari harga pasar. Aspek-aspek pemasaran merupakan penjualan hasil ikan dijual dengan ketentuan harga jual pasar (Gambar 1). b) Penjualan dilakukan dengan cara diambil pelanggan dan harga jual harga jual rata-rata $\mathrm{Rp}$ $17.000 / \mathrm{kg}$ dan merupakan harga yang berlaku di pasar (Gambar 2) dengan hasil produksi ikan nila $2,600 \mathrm{~kg}$ per $1000 \mathrm{~m}^{2}$ dijual dalam bentuk glondongan atau konsumsi.

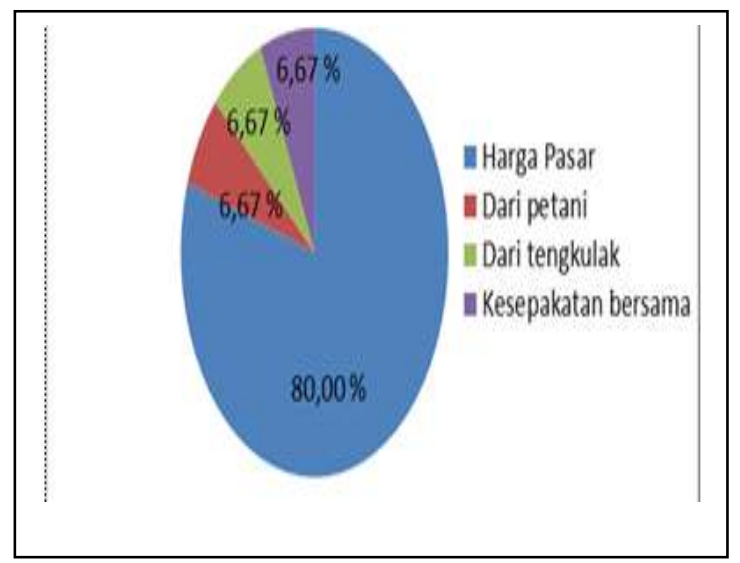

Gambar 1. Pengelompokkan petani ikan berdasarkan penentuan harga jual

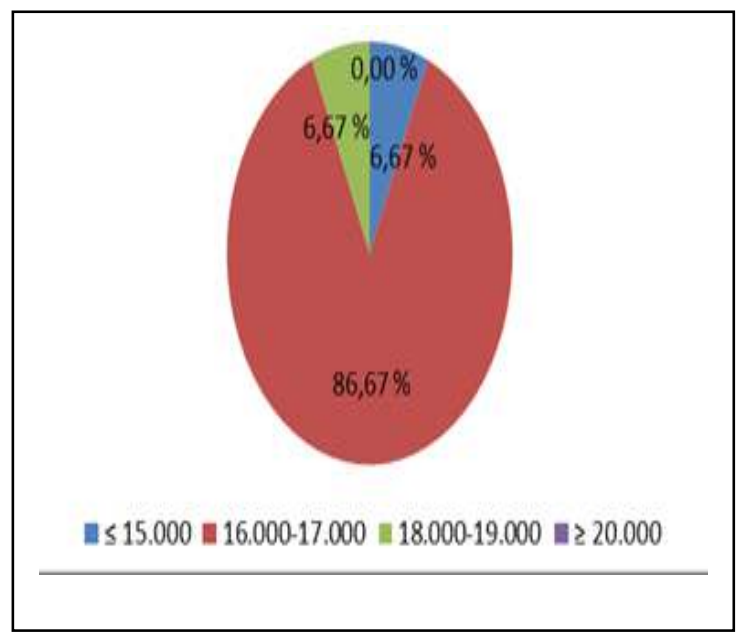

Gambar 2. Pengelompokkan berdasarkan Harga Jual (per kg)

c) Berdasarkan Gambar 3. petani biasanya menjual hasil-hasil usahatani mereka sendiri didaerah setempat dengan cara berlangganan sebanyak 93,33\%. Karena itu menjadi daya tarik bagi petani untuk memproduksi barang-barang untuk dijual bukan sekedar untuk dimakan sendiri, lebih banyak tergantung pada hargaharga setempat. Jadi para petani harus memenuhi kriteria ikan sesuai dengan permintaan pembeli baik itu ikan berupa benih, glondongan atau konsumsi.

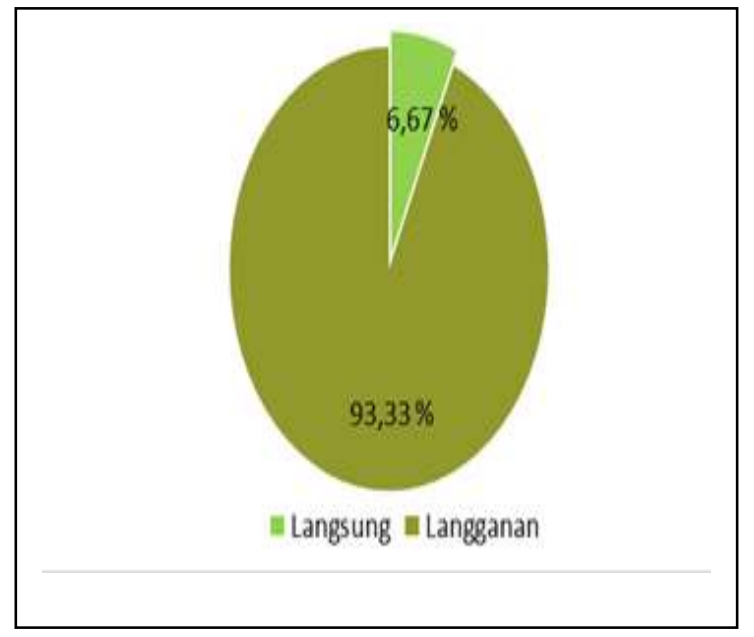

Gambar 3. Pengelompokkan petani ikan berdasarkan teknik penjualan

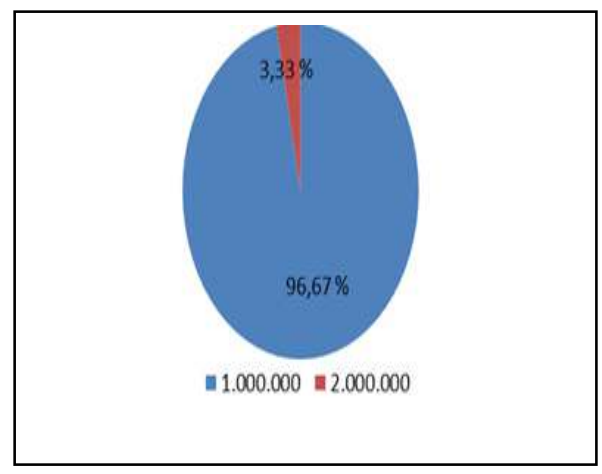

Gambar 4. Pengelompokkan petani ikan berdasarkan pendapatan bersih per bulan

d) Pendapatan usahatani adalah selisih antara pendapatan kotor (output) dan biaya produksi (input) yang dihitung dalam per bulan, per tahun, per musim tanam. Soekartawi (1995) Pendapatan usahatani adalah selisih antara total penerimaan dan semua biaya yang dikeluarkan. Berdasarkan diagram diatas menunjukkan bahwa petani mampu memperoleh pendapatan bersih rata-rata

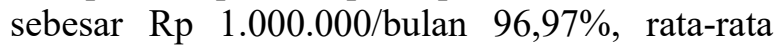
petani dapat memenuhi kebutuhannya dengan usahatani budidaya ikan.

\section{Kesimpulan}

Berdasarkan tujuan penelitian disimpulkan bahwa $83,33 \%$ petani berada pada usia produktif; $80 \%$ pendidikan formal petani hanya mencapai SD-SLTP; $86,67 \%$ rata-rata jumlah tanggungan keluarga yaitu 3 orang/keluarga; $90 \%$ petani ratarata berpengalaman 5 tahun - 10 tahun; rata-rata produksi ikan mencapai $2.600 \mathrm{~kg}$ per periode usaha; sistem penjualan dengan cara berlangganan dengan tengkulak yang mengambil langsung ke lahan usaha,dengan harga jual rata- 
rata $\mathrm{Rp} 17.000 / \mathrm{kg}$ dan merupakan harga yang berlaku di pasar. Dengan sistem tersebut petani mampu memperoleh pendapatan bersih rata-rata sebesar Rp 1.000.000/bulan. Secara umum disimpulkan bahwa karakteristik sosial ekonomi petani sangat berpengaruh terhadap kinerja usahatani pembudidaya ikan air tawar. Disarankan perlunya peran serta kelembagaan dan jiwa kewirausahaan untuk mendorong tercapainya produksi yang optimal. Dengan demikian tingkat keuntungan yang diperoleh petani dari hasil usahataninya dapat dinaikkan.

\section{Daftar Pustaka}

BPS, 2014. Tabel Dinamis Produksi Ikan Darat menurut Jenis Budidaya dan Kabupaten/Kota di D.I. Yogyakarta.

Denta, D. 2008. Proses Pembentukan Kelompok dan Hubungan Partisipasi Anggota Dengan Kinerja Kelompok Dalam Usaha Agribisnis Lidah Buaya (Aloe Vera). Fakultas Pertanian Universitas Brawijaya. Malang.

Koentjaraningrat. 1997. Metode-Metode Penelitian Masyarakat. Edisi ke-3. PT. Gramedia Pustaka Utama. Jakarta.

Mardikanto, T. 1995. Penyuluhan Pembangunan Pertanian. UNS. Surakarta.

Mosher, A.T. 1987. Menggerakkan dan Membangun Pertanian Sebelas Maret. Universitas Press. Surakarta.

Nasir, M., 2003. Metode Penelitian. Ghalia Indonesia. Jakarta.

Payaman J.S. 1985. Pengantar Ekonomi Sumber Daya Manusia. Jakarta: Lembaga Penerbit Fakultas Ekonomi Universitas Indonesia.

Pingali P. 2006. Agricultural Growth and Economic Development: a view through the globalization lens. Presidential Address to the 26th International Conference of Agricultural Economists, Gold Coast, Australia, 12-18th August, 2006.

Riduwan, 2002. Skala Pengukuran VariabelVariabel Penelitian. IKAPI. Jawa Barat.

Shaw. 1979. Group Dymanic : The Psycology of Small Group. Mc Graw-Hill Publishing Company. New Delhi.

Situngkir, Sihol. Lubis Pulina dan Erida. 2007. Peranan Ibu Rumah Tangga Dalam
Meningkatkan Pendapatan Keluarga (Kasus: Pedagang Sayur di Kota Madya Jambi). "Jurnal Manajemen dan Pembangunan”, Ed. 7, Juli 2007.

Soekartawi. 1988. Prinsip-Prinsip Dasar Komunikasi Pertanian. Fakultas Pertanian Universitas Brawijaya. Malang.

Soekartawi,1995.Analisis Usahatani. UI. Jakarta.

Sunar. 2012. Pengaruh faktor biografis (usia, masa kerja, dan gender) terhadap produktivitas karyawan (studi kasus PT Bank X). Forum Ilmiah, 9(1): 167 - 177.

Widodo, S., Nawang S.P. 2015. Dinamika Pembangunan Pertanian. Yogyakarta. 